\title{
FROM WAR ECONOMIES TO PEACE ECONOMIES IN AFRICA
}

\author{
Amelia Broodryk and Hussein Solomon \\ Department of Political Sciences \\ University of Pretoria
}

\begin{abstract}
One reason for the persistence and protracted nature of conflict on the African continent is the phenomenon of war economies. These have transformed the nature of war itself where the object is not at neutralizing an enemy but to institutionalize violence at a profitable level of intensity. Transforming war economies into peace economies constitute a unique challenge to post-conflict reconstruction strategies on the African continent. This article explores these challenges and critically examines whether the African Union (AU) and New Partnership for Africa's Development (NEPAD) post-conflict reconstruction strategies meets these challenges. The article concludes with some recommendations to policy-makers in order to ensure that this transition from war to peace economies does indeed take place in order to ensure a more peaceful continent.
\end{abstract}

\section{Introduction}

The emergence of economic agendas during times of conflict is not a new phenomenon; rather, it represents an integral part of warfare throughout history. For example, during the Thirty Years' War in Europe from 1618-1648, war became an important source of profit. ${ }^{1}$ Since 1945 , conventional interstate wars have occurred less frequently, and intrastate wars have become the prevailing form of conflict in the world. Studies of intrastate conflicts have traditionally focused on the political dimensions, with discussion of the economic dimension often limited to "the role played by economic deprivation or resource scarcity in the eruption of violent conflict". 2 However, the last decade has seen a steady appearance of literature exploring the economic dimensions of armed conflict in more detail. The significance of economic agendas in armed conflict has been frequently debated; 
nevertheless, there is certainly a need to take into consideration the economic dimension to understand "the causes and the persistence of conflict". 3

During the early to mid-1990s, studies of economic agendas during armed conflicts attempted to address the issue of endurance by focusing on the costs of conflict through three main approaches. The first approach viewed conflict "as a temporary 'interruption' to an ongoing process of development". ${ }^{4}$ The second approach, traditionally associated with peace and conflict studies, highlighted the influence of miscommunication on the occurrence and endurance of conflict. The third approach concentrated on the potential recurrence of "ancient hatreds" and "long-suppressed animosities" between conflicting parties. ${ }^{5}$

Since the late 1990s, an increasing number of policy and academic studies have explored the economic dimension of conflict in more detail, moving away from the traditional conceptions of the role played by economics during conflict. This includes a greater focus on issues such as the role of resource abundance and scarcity on conflict, or the so-called "greed versus grievance" argument, made popular by Collier ${ }^{6}$ and discussed in detail by authors such as Berdal and Malone, ${ }^{7}$ Ballentine and Sherman, ${ }^{8}$ and Collier and Hoeffler. ${ }^{9}$ Related to the greed versus grievance debate is the emergence of war economies in countries experiencing civil conflict. The war economies that emerge from civil conflict are very different from the traditional war economies of interstate wars. According to Ballentine and Sherman ${ }^{10}$, civil war economies are "parasitic", "illicit" and "predatory" and they "rarely contribute to state capacity or economic development".

In many African countries such as Sierra Leone, Angola and the Democratic Republic of Congo, conflict actors create a distinct war economy in order to maintain the conflict in that country. The development of war economies "challenge[s] the core assumptions that have informed thinking and guided policy with respect of civil wars and internal conflict in the 1990s". ${ }^{11}$ The traditional military objective of defeating an enemy is "replaced by economically driven interests in continued fighting and the institutionalisation of violence at what is for some clearly a profitable level of intensity". ${ }^{12}$ The end goal is not to win the war; rather, it is to make a profit from the instability created by the conflict. Consequently, the longer a conflict endures, the more money and resources these "war profiteers" accumulate. Reno ${ }^{13}$ describes the appearance of "warlords" in areas such as West Africa, who dominated the political and economic arena in order to serve their own business interests.

The increase in self-reliant economic activity by combatants is an indication of the changing nature of world political and economic trends since the 
end of the Cold War. Traditional sources of funding, such as foreign state patronage, were no longer available to conflict parties, and consequently they had to rely on other means of financing, such as looting, smuggling and extortion. In addition, "rapid economic globalization and the replacement of state-led development by market-driven free trade have created new and abundant opportunities for more systematic forms of combatant self-financing". ${ }^{14}$

As mentioned above, the enduring nature of the war economies presents a unique challenge to actors involved in ensuring peace returns to a country through a peacebuilding strategy. Although post-war rebuilding occurred during the reconstruction of Europe and Japan after the Second World War, the terms "postconflict peacebuilding" and "post-conflict reconstruction" only came to prominence during the mid-1990s. The two terms are often used interchangeably; however, this article uses "post-conflict reconstruction" to describe the complex process of transforming a country from war to peace, as the term focuses on the technical aspects of rebuilding after conflict.

Post-conflict reconstruction strategies encompass several areas that are affected by conflict, including the political, social and economic spheres. However, only certain aspects of political economy are targeted by current post-conflict reconstruction policies and specific features of war economies are often neglected. According to Pugh, Cooper and Goodhand ${ }^{15}$, the consequences of this neglect may include an underestimation of the challenges in achieving peace agreements, the possibility of a relapse into conflict, and the problem that "economic criminals" may still have access to resources after a conflict has ended. In addition, these types of actors often play the role of peace spoilers, reneging on the commitments they may have made in peace agreements.

This article will focus on the challenges of transforming war economies into peace economies in Africa by firstly providing an overview of the key concepts "war economy", "peace economy", "post-conflict peacebuilding" and "post-conflict reconstruction". Secondly, the specific characteristics of war economies are discussed. Thirdly, the process of post-conflict reconstruction is explained within the peacebuilding framework. Finally, concluding remarks and recommendations are made. The main aim of this article is to highlight the various challenges posed by the process of transforming war economies to peace economies, and how this has become increasingly problematic in the search for long-term peace and stability in Africa. 


\section{Overview of key concepts}

The past few years has seen a burgeoning of literature on the subject of economic agendas in conflict. However, these concepts are not always used in the same way by scholars belonging to different schools of thought or, indeed, different disciplines. For purposes of clarity, then, concepts like "war economy", "peace economy" and post-conflict peace-building are examined below.

\section{- War economy}

According to $\mathrm{Naidoo}^{16}$, "the term 'war economy' has been used to conceptualise the sustainability of an intractable conflict through the expropriation and exploitation of a country's resources by warring parties". Political elites and rebel movements are generally the custodians of war economies: the former use national armies to advance business projects (often for private financial gain), while the latter take control of strategic locations with definite commercial profitability.

Pugh et al ${ }^{17}$ use a simpler definition, stating that the term is used to include all economic activities carried out during wartime. However, Goodhand ${ }^{18}$ breaks the term "war economy" into three categories, namely the combat economy, shadow economy and coping economy, in order to differentiate between the actors involved, and activities carried out during a conflict.

According to Fekete $^{19}$, war economy refers to "a set of economic structures that arise from armed conflicts and that may continue to exist even after the violence has ended". A war economy "has to do with making money out of a war system rather than out of a peaceful situation". ${ }^{20}$ Berdal expands this definition by mentioning the relationship that develops between specific actors involved in the development of a war economy. He states:

... elites, ordinary people caught up in war, and external actors that stand to gain from a conflict have vested interests in continuing a specific conflict. As time passes, such interests will crystallise into a distinctive war economy, usually forming part of a regional pattern of informal economic activity. ${ }^{21}$

War economies are costly and catastrophic for societies as a whole; however, they may be highly profitable and lucrative for individuals, groups within society and outside actors. ${ }^{22}$ Any valuable discussion about war economies must include an investigation of the role that natural resources play in perpetuating these economic systems. 


\section{- $\quad$ Peace economy}

A peace economy can very simply be defined as the opposite of a war economy. Although it may utilise a similar economic structure and the same means, for example trade, the result of peace economies is more even growth. ${ }^{23}$ Peace economies also operate in a completely different environment, that of peace, where insecurities are not linked to violence.

These economies are able to attract legitimate foreign direct investment (FDI), where war economies cannot, at least not in a positive or legal fashion. ${ }^{24}$ The profits made out of a peace economy are ideally used towards development projects, overall income and economic growth. War economy profits go towards funding the conflict or enriching elites. ${ }^{25}$ A peace economy will ideally be a situation where all war economy challenges have been adequately addressed. Most importantly, a peace economy represents the end-result of a post-conflict reconstruction strategy, and therefore, essentially representing positive peace - an essential element to notions of human security.

Finding a precise definition of what is meant by "peace economy" is difficult because actors involved in the process will view "peace" differently. There is a growing debate amongst academics and peace practitioners around whether following the "liberal peace" model of post-conflict reconstruction is ultimately the most successful.

The liberal peace reflects the Western understanding of the concept "peace", which includes the promotion of democratisation, the rule of law, and neoliberal economic policies, amongst others. ${ }^{26}$ Although the pursuit of these principles is important for building peace, the manner in which they are pursued usually reflects a top-down approach. It therefore indicates the beliefs of international actors (who traditionally drive the post-conflict reconstruction process) and does not the take into account the views of local populations. In addition, the "winners" of wars often determine what kind of peace will be built. ${ }^{27}$

A new understanding of the liberal peace is needed; one that incorporates the views of the local populations, and then the ideas of international actors involved in post-conflict reconstruction strategies. Moreover, post-conflict reconstruction often fails to differentiate between civil society actors, grouping together all actors but the state. This means that some stronger or more influential civil society actors, such as businesses, may benefit more from reconstruction than others. More worryingly is the tendency of those implementing reconstruction strategies to talk 
about including local stakeholders in determining their own economic future, but not doing this in practice. ${ }^{28}$

According to Woodward" ${ }^{29}$, "[t]he war economies that must be transformed to peacetime economies in contemporary cases of civil war are not emergency adjustments to an otherwise normal economy but an entire transformation of social and political institutions". Therefore, international financial institutions and other aid donors involved in reconstruction processes must adjust their macroeconomic and fiscal policies in order to prevent war economy actors from gaining access to funds and diverting these away from rebuilding the state economy. It is also vital to understand how "local, microeconomic practices interlink with state, regional and global aspects of war economies" in order to build sustainable peace. ${ }^{30}$

In Sierra Leone, for example, the neo-liberal economic policies promoted by international financial institutions in the 1980s and 1990s actually undermined rather than rebuilt the state. During this time, the various leaders in Sierra Leone were able to use international financial institution demands for "reductions in state expenditure, privatization, and the use of foreign firms to weaken rivals and reward their own patrons". ${ }^{31}$ This practice aggravated tensions within the local society and hindered the peace process.

Overall, the pursuit of a peace economy should be reflected in the postconflict reconstruction strategy for a country emerging from conflict. The economic dimensions of post-conflict reconstruction should complement the other dimensions of post-conflict reconstruction, including the promotion of justice and human rights.

In addition, works by authors such as Johan Galtung on the difference between negative and positive peace are important for a discussion about postconflict reconstruction because such works determine whether a broad or narrow approach to peacebuilding should be used. According to Galtung, ${ }^{32}$ peacebuilding encompasses "the practical aspects of implementing peaceful social change through socio-economic reconstruction and development". Galtung also includes peacebuilding under a "third generation" of peace approaches that have emerged in the post-Cold War era. This "third generation" recognises the deep-rooted nature of conflict and its impact on development. Although the initial work of Galtung on positive and negative peace has become less prominent, what has emerged is a focus on the link between positive peace and the notion of justice. Overall, "positive" postwar peacebuilding should not only include plans for socio-economic and political reconstruction, but also promote social justice and reconciliation. ${ }^{33}$ 
According to Spear ${ }^{34}$, "focusing on political economies for peace is a relatively new research agenda for those working on post-conflict peace building [sic] and takes as a point of departure the work done on war economies". Spear also argues that a peace economy has to be more attractive for actors that were involved in the war economy.

- $\quad$ Post-conflict peacebuilding

The theme of "peacebuilding" was popularised by Boutros BoutrosGhali's An Agenda for Peace in 1992. According to this document, the objective of peacebuilding is broad and includes removing "underlying economic, social, cultural and humanitarian problems" and facilitating "the transformation of deficient national structures and capabilities". ${ }^{35}$ In addition, conflict is considered a linear process, linking peacebuilding with the post-conflict period, and including the processes of conflict prevention, peacemaking and peacekeeping. Therefore, peacebuilding is understood as "post-conflict peacebuilding", as the peacebuilding process would only be implemented after all the other conflict processes had been executed. ${ }^{36}$

In 1995, Boutros-Ghali presented the Supplement to An Agenda for Peace on the Fiftieth Anniversary of the United Nations. The document acknowledged the problematic conception of peacebuilding as set out in An Agenda for Peace. Consequently, Boutros-Ghali expanded the function of peacebuilding and combined it with conflict prevention and conflict management. The focus of peacebuilding thus included the entire conflict spectrum, and not post-conflict settings exclusively. ${ }^{37}$

This expanded understanding of peacebuilding only contributed to increased perplexity, so in 2001 , the UN Security Council attempted to clarify the broad definition of peacebuilding, stating that the process would foster activities such as "sustainable development", "transparent and accountable governance" and the "promotion of democracy". ${ }^{38}$ This again created a certain level of uncertainty as to the scope of peacebuilding, as many activities that were now considered under the peacebuilding umbrella could actually be considered part of development strategies and the support for democratisation. It is important to note, however, that the focus of peacebuilding remained on conflict, thus separating itself from other non-conflict processes. $^{39}$

The broad usage of the term "peacebuilding" has resulted in the term becoming vague, and it is often unnecessarily contested, which results in inconsistencies in analysis, policy and practice. The definition of the concept is adapted according to the institutional needs of the actors involved. Hänggi 
distinguishes between the broader concept of peacebuilding, which extends beyond post-conflict societies to include activities that occur during conflict and in the absence thereof, and the narrower understanding, which is limited to post-conflict environments. Therefore, Hänggi uses the term "peacebuilding" to describe the broad understanding of the process, and adds "post-conflict" to "peacebuilding" in order to denote the narrow definition of the concept. ${ }^{40}$

For the purpose of this article, the narrower understanding of the concept is used, as the focus of the study on which this article is based, was on the postconflict environment. It is necessary to explain why the term "post-conflict reconstruction" is preferred over the term "post-conflict peacebuilding". A perusal of the literature reveals that, generally, the terms are defined and used interchangeably. Taking into consideration the disagreement on a precise definition of peacebuilding, as the discussion above reveals, it was be to the benefit of the study to move away from this environment. In addition, because the study dealt specifically with the transformation of war economies, the term "post-conflict reconstruction" more adequately reflects this practice. This is not to conclude that the term only refers to the economic dimensions of rebuilding a country after conflict, as has sometimes been incorrectly assumed. Rather, it reinforces the notion that one of the key areas of post-conflict reconstruction is the socio-economic rehabilitation of a country, a process that must be executed in direct coordination with other dimensions of post-conflict rebuilding. The preference of the use of the term "post-conflict reconstruction" also takes into account the trends of the African Union (AU) and the New Economic Partnership for Africa's Development (NEPAD) Secretariat documents. As this is a study about Africa, it is only logical to use terms that are being promoted by African institutions, and which would be much more accessible to African scholars.

\section{- $\quad$ Post-conflict reconstruction}

The concept of post-conflict reconstruction has steadily broadened in scope since the 1990s. Depending on the institution or actor involved, the term will have a different meaning. According to the Centre for Strategic and International Studies (CSIS), ${ }^{41}$ reconstruction takes place between cessation of violent conflict and return to "normalisation". The economy forms part of one of the "four pillars" identified in the CSIS framework, which includes security, justice and reconciliation, social and economic well-being, and governance and participation. This framework was used as a model for the New Partnership for Africa's Development (NEPAD) Secretariat's 2005 Post-Conflict Reconstruction Policy Framework. 
Post-conflict reconstruction is a holistic strategy that includes several dimensions. According to the 2005 NEPAD Secretariat policy framework, these dimensions should include security, political transition, socio-economic development, human rights and resource mobilisation. ${ }^{42}$ Since this article is focused on the transition from war economy to peace economy, the economic component of post-conflict reconstruction will be discussed in depth.

According to a World Bank definition, post-conflict reconstruction is a process that "supports the transition from conflict to peace in an affected country through the rebuilding of the socio-economic framework of the society". 43

Reconstruction provides a good base for a country in order to reach the stage of sustainable development. Post-conflict reconstruction does not solely refer to the reconstruction of actual physical infrastructure; it also includes all plans to rebuild a society - politically, socially, militarily and economically - and attempts to address the root causes of conflict. Reconstruction is a lengthy, non-linear, and uncertain process. $^{44}$

According to the School of Advanced International Studies (SAIS),

... peacebuilding or post-conflict reconstruction is a process that facilitates the establishment of durable peace and tries to prevent the recurrence of violence by addressing root causes and effects of conflict through reconciliation, institution building and political as well as economic transformation (School of Advanced International Studies 2006). ${ }^{45}$

Plans for post-conflict reconstruction should ideally be included in negotiated peace agreements in order to create an environment where sustainable reconstruction can be possible. Post-conflict reconstruction is mostly recognised as a multi-dimensional and multi-sectoral activity. The complex nature of post-conflict reconstruction renders results only in the medium to long term and evaluation of the success or failure of efforts is particularly difficult. ${ }^{46}$

\section{The challenge of war economies}

While the emergence of war economies is not a new phenomenon, the "specific configuration of localized wars, shadow economies and the globalization of illegal economies" has developed into a new kind of political economy with strong links to conflict. $^{47}$ War economies have the remarkable ability to evade national governments and international law by challenging domestic and international financial regulations. To summarise, war economies "refer to the economic 
mechanisms that allow actors, including all types of state and non-state actors, to conduct wars or to participate in violent conflict". ${ }^{48}$ In the case of Sierra Leone, the environment created by the strong Shadow State ${ }^{49}$ helped bring about conflict in 1991 and enabled a war economy to develop. The economic system of Sierra Leone was, at that time, so closely tied to the elite-run political system that once the Revolutionary United Front (RUF) attacked, the elite of the country could continue to use the country's resources to protect and maintain themselves at the expense of thousands of ordinary citizens.

In his discussion of war economies, Duffield ${ }^{50}$ offers a different view on the concepts or "war" and "peace", stating that both are state-centred terms, and that they were appropriate for a time when only nation-states had the power to start and end wars. War economies, therefore, "not only have similar transnational and networked characteristics to the conventional global economy, at national level, they have a good deal in common with the relations and structures that constitute the peace economies of the regions in which they operate". 51 In many parts of the world, war and peace have become relational terms, and due to similar internal structures and interactions with the outside world, the terms are only distinguishable by the presence of sustained violence. Given the problems with using a state-centric approach when analysing war economies, Duffield ${ }^{52}$ proposes the use of the "postnation-state" conflict. This concept overcomes the traditional view of conflict as being "temporary", "irrational" and "backward" and reflects the shift towards a broadened understanding of conflict and the impact of war economies.

Although war economies have distinct features, they often become so entrenched in the everyday operating economy that they become difficult to identify. Most war economies operate parallel to the economy of a country but can also merge, overlap and distort that economy. According to Ballentine and Nitzschke, ${ }^{53}$ the distinctive features of war economies are the following:

- They involve the destruction or circumvention of the formal economy and the growth of informal and black markets, effectively blurring the lines between the formal, informal, and criminal sectors and activities.

- Pillage, predation, extortion and deliberate violence against civilians are used by combatants to acquire control over lucrative assets, capture trade networks and diaspora remittances, and to exploit labour. 
- War economies are highly decentralised and privatised, both in the means of coercion and in the means of production and exchange.

- Combatants increasingly rely on the licit or illicit exploitation of/trade in lucrative natural resources where these assets are available.

- Combatants, thus, thrive on cross-border trading networks, regional kin and ethnic groups, arms traffickers and mercenaries, as well as legally operating commercial entities, each of which may have a vested interest in the continuation of conflict and instability.

War economies today differ fundamentally from war economies in the past in several respects. The most prominent difference is that traditional war economies focused on using resources to defeat the enemy in battle. Therefore, the economy of the state was geared to building up a defence force capable of winning a war. Today's war economies do the opposite, as "they involve the fragmentation and decentralization of the state" ${ }^{54}$ In other words, the state cannot monopolise production and employment in order to fund their war cause. Instead, outside actors are brought in to support warring parties in their quest to win a conflict. Ordinary civilians become targets of violence and predation, and state resources are traded outside of the country to private companies who have no political interests, and only wish to make a profit. ${ }^{55}$

Goodhand ${ }^{56}$ divides the concept "war economy" into three categories: the combat economy, the shadow economy and the coping economy. These three economies will overlap, but this categorisation process simplifies matters by separating the different actors, motives and activities during armed conflict. In a combat economy, the key actors include commanders, "conflict entrepreneurs", fighters, and suppliers of weapons. Military objectives will ensure a conflict is sustained in order to maintain power, status or wealth. Peace can only really be an option if an alternative plan includes viable livelihood strategies. The activities that fall under the combat economy include the taxation of legal or illegal combat equipment and arms, as well as asset stripping and looting and the manipulation of aid.

The shadow economy focuses more on economic actors such as businessmen, drug traffickers and profiteers, especially in the field of diamond smuggling and illegal commodity sales. The shadow economy operates on the margins of the conflict (thus bringing in regional and international networks). In 
order for peace to be obtained here, a direct attack has to be made on the illicit networks created by this specific system; otherwise, a criminalised peace economy will be created. The shadow economy has strong links with the shadow state, because shadow state actors create the shadow economy. In their analysis of Sierra Leone's war economy, Pugh et $\mathrm{al}^{57}$ argue that the war economy utilised existing shadow trade networks within the West African region.

The coping economy focuses on the poor communities who rely on subsistence or basic services in order to survive. Any successful reconstruction strategy would have to focus on job creation, humanitarian and rehabilitation assistance, and overall access to socio-economic rights. This strategy would also have to take into account what these groups have done for themselves.

Civil war has an inevitable impact on those not directly involved in the immediate fighting. The people living in a specific area where rebels or government soldiers may be fighting often find themselves victims of looting. These people lose cattle, houses and other belongings due to pillaging. In order to prevent further losses, people often shift their movable assets abroad. Studies have shown that before conflict, the typical civil war country holds 9 per cent of its private wealth abroad, and by the end of a civil war, 20 per cent of this wealth will be held abroad. The average overall capital flight numbers are most likely far higher than recorded. ${ }^{58}$

Economic losses due to civil war are not just created by the diversion of resources from production, but also the damage caused by these resources when they are used to aid violence. The infrastructure of a country can be completely devastated by both government and rebel groups, as ports, airports, roads, bridges and telecommunication lines are strategic targets. Rebel and government soldiers also often loot and destroy houses, schools and health facilities.

During civil war, governments increase military expenditure and this would certainly reduce spending on development projects and on promoting economic growth. Collier et $\mathrm{al}^{59}$ define a developing country as one with less than USD 3000 per capita gross domestic product (GDP) at 1995 USD rates. Such a developing country spends an average of 2,8 per cent GDP on the military during peacetime. A sharp decrease in public expenditure, such as on infrastructure or health, will have negative consequences for incomes and social indicators. According to this view, civil war disrupts the normal investment time horizons, and families and community links are often severed. ${ }^{60}$

War has both positive and negative effects on a country's economy; however, war generally obstructs legitimate economic development and undermines overall prosperity. Traditionally, the most consistent short-term economic effect of 
war is to push up commodity prices and, consequently, the standard of living is reduced. Present-day wars, especially civil wars, continue to fuel inflation and drive currencies towards worthlessness. Another negative effect of war is severe capital depletion. Usually during war, capital such as farms, factories and cities are destroyed and thus economic output is severely depressed. ${ }^{61}$

Civil wars are very costly to an economy. However, civil conflict creates opportunities for profit that are not usually available during peacetime. This distinguishes the profit made during wartime from that made in a peace economy. It is important to note that both peace and war economies utilise the existing structures and networks available. The positive and negative effects come into play when actors abuse the system, by trading illegal goods to buy arms, for example.

Collier $^{62}$ mentions four specific civil war profit opportunities. Firstly, he argues that life during civil war becomes increasingly less predictable. The result is that people who would have sought long-term business opportunities shorten their time horizons. This is logical, as it does not make good business sense to invest in an area that is expected to become unstable. Secondly, civil war brings with it increased criminal activity, as governments spend money on the military rather than police services. This means that the risks of punishment for crime decrease, resulting in an increase of crimes such as theft. Thirdly, markets are always disrupted by instability during civil war. Fourthly, trade becomes more monopolistic as competition decreases. Finally, rent-seeking predation on trade increases for rebels, and may even increase for government officials, as their actions become less open to scrutiny.

Primary commodities play an enormous role in war economies. The reason for this is because primary commodity exports are the most lootable of all economic activities. These commodities are heavily taxed and exports of such commodities are vulnerable because their production relies heavily on long-lasting and immobile assets. $^{63}$ In the case of Sierra Leone, legal and illegal trade in diamonds had a great impact on determining the intensity and endurance of the conflict in that country. In modern war economies, the informal economy usually dominates because the formal government economy is not functional or simply does not exist - this is certainly the case during times of civil war.

War is very often, especially in "development" literature, portrayed as an interruption in a process of (positive) development and a major disruption to the economy as a whole. However, war is not always purely destructive and political scientists and economists often only see the chaos created by contemporary civil wars rather than exploring the new system of profit, power and protection. ${ }^{64}$ 
Warring sides need to sustain themselves financially, and the important question arises of how they accomplish this exactly. The economic theory of conflict thus does not focus on the motives for the start of a conflict, but rather on how long it can remain financially viable. Several economic characteristics of a country could potentially contribute to creating a conflict situation. One of these characteristics is the dependence of a country's GDP on primary commodities. The reason for this is the fact that primary commodity exports are the most lootable of all economic activities due to their enduring and fixed nature. However, characteristics such as these do not act in isolation, and are supplemented by political, cultural and religious factors.

The civil war and civil war economy of a specific state do not solely affect that state. Civil war has a severe impact on the economies of surrounding countries as well as economic regions. Throughout these regions, economic growth tends to decline and investment flows, especially foreign investment, diminish or disappear altogether. ${ }^{65}$ However, in some regions, such as West Africa, shadow or illegal trading networks continue to operate even during times of conflict.

Conflicts have been protracted by the use of transnational economic links; these rely mostly on the smuggling of a state's natural resources for the supply of military hardware required for sustaining a war. Contemporary access to global markets has been based on transcontinental smuggling networks for the sale of highly valued commodities, including precious minerals, hardwoods, contraband drugs, arms, fuel, equipment and food. ${ }^{66}$

This is certainly the case for the Democratic Republic of the Congo (DRC), where resources, including diamonds, gold, copper, oil and uranium gas are found in abundance and yet the annual per capita income of 69 million people is under $\$ 300 .{ }^{67}$ The trading of "conflict minerals" (raw materials sourced from war zones) is particularly problematic in this region, and groups such as Global Witness have recently urged cell phone manufacturers to buy only conflict-free minerals for use in their products. ${ }^{68}$

\section{A discussion of post-conflict reconstruction}

Developing and implementing a framework for post-conflict reconstruction is quite a challenging undertaking, not only because of the lack of accurate data and information concerning the process, but also because of the broad scope of post-conflict reconstruction as a strategy. A post-conflict reconstruction strategy should also aim at addressing the root causes of conflict, creating 
sustainable peace, promoting social justice, and renewing participatory governance within a country. ${ }^{69}$

Post-conflict reconstruction is an intricate multi-dimensional process of transformation from war to peace that supplies synchronised short-, medium- and long-term programmes. The process is aimed at addressing the root causes of conflict, and paves the way for sustainable peace. Post-conflict reconstruction moves through three variable phases: the emergency phase, the transition phase and the development phase. These phases should not be seen in a specific linear fashion, as they can overlap and intersect. The process starts once hostilities in a country have ended, usually indicated by the signing of a peace agreement or a cease-fire agreement. $^{70}$

According to the Organisation for Economic Cooperation and Development (OECD), post-conflict reconstruction incorporates three equally important key focus areas, namely the security dimension, the political dimension, and the socio-economic dimension. ${ }^{71}$ The Norwegian Ministry of Foreign Affairs utilises a similar framework in its approach to post-conflict reconstruction. This is important to note as it gives an indication of donor approaches to post-conflict reconstruction. ${ }^{72}$ The Centre for Strategic and International Studies (CSIS) utilises a similar approach as that of the OECD, but adds a fourth "pillar" of justice and reconciliation. ${ }^{73}$

The NEPAD Secretariat makes use of five dimensions: security; political transition, governance and participation, socio-economic development, human rights, justice and reconciliation, and coordination, management and resource mobilisation. ${ }^{74}$ The last dimension is particularly relevant for Africa due to the occurrence of resources-based conflicts.

More recently, the African Union (AU) developed a framework for postconflict reconstruction and development (PCRD), which focused on developing policy and implementation guidelines for post-conflict reconstruction practitioners. The AU PCRD makes use of six elements: security; humanitarian/emergency assistance; political governance and transition; socio-economic reconstruction and development; human rights, justice and reconciliation; and women and gender. ${ }^{75}$

In 2005, United Nations resolution 60/180 and Security Council resolution 1645 (2005) of 20 December 2005 established the Peacebuilding Commission. The Commission was mandated to perform three key tasks:

- firstly, to "bring together all relevant actors to marshal resources and to advise on the proposed integrated strategies for post conflict peacebuilding and recovery"; 
- secondly, to "help ensure predictable financing for early recovery activities and sustained financial investment over the medium to long-term"; and

- lastly, to "develop best practices on issues in collaboration with political, security, humanitarian and development actors". 76

In June 2006, the UN Peacebuilding Commission selected Sierra Leone and Burundi as its first case studies. The Commission developed a Sierra Leone Peacebuilding Cooperation Framework, which included a focus on the challenges and risks associated with peacebuilding, mutual commitments, and a review and tracking of progress of the reconstruction process. At a preliminary country-specific meeting in 2006, the government of Sierra Leone outlined a number of challenges for achieving sustainable peace including, "social and youth empowerment and employment", "consolidating democracy and good governance, justice and security sector reform", and "capacity building". 77 In Burundi, the Commission and the government of Burundi agreed on four critical areas to form the foundation of a strategic framework, namely promoting good governance, strengthening the rule of law, reform of the security sector, and ensuring community recovery with a special focus on youth. ${ }^{78}$

There are a number of practical issues attached to the post-conflict reconstruction frameworks discussed above. Firstly, it should be understood that the key areas mentioned in each framework do not operate in isolation, and they must be put into practice simultaneously in order to develop an acceptable level of momentum for development. Secondly, any post-conflict reconstruction strategy should take into account the specific conflict system in a country by creating a unique strategy for that country. Thirdly, post-conflict reconstruction strategies should also incorporate regional issues, as no country operates in isolation and it is important to coordinate strategies in order to avoid unnecessary conflict in the future. Finally, there must be a sense of local ownership if any post-conflict reconstruction strategy is to succeed. This is not limited to informing and educating the local population about the plans that will be implemented; it means consulting these actors during the development of the strategy, as well as its execution. ${ }^{79}$ As post-conflict reconstruction is largely an external actor-driven process, this last issue could become very problematic. It is therefore vital that all the actors involved in the process of developing a post-conflict reconstruction framework are aware of the challenges involved.

This article focuses on the socio-economic dimensions of the post-conflict reconstruction strategies put forward by the NEPAD Secretariat, the AU and the UN peacebuilding framework as these specifically pertain to the issue of war economies. 
The UN framework is particularly relevant because it is country-specific, whereas the NEPAD Secretariat and AU strategies are more general, but also have an African focus. It is important to consider all three strategies, because each has distinct characteristics.

The socio-economic dimension of post-conflict reconstruction can particularly tackle the problem of transforming war economies to peace economies. According to Hänggi, ${ }^{80}$ the socio-economic dimension incorporates the following challenges:

- repatriation and reintegration of refugees and internally displaced persons;

- reconstruction of infrastructure and important public functions;

- development of education and health; and

- $\quad$ private sector development, employment, trade and investment.

The NEPAD Secretariat devised a reconstruction system that incorporates the five sectors mentioned earlier. The reconstruction of a post-conflict country must include all spheres of society. Reconstruction activities will overlap both in terms of timing and focus. Post-conflict reconstruction is one "umbrella" strategy with several coordinated branches. Coordination is very important, otherwise resources may be squandered or groups may be ignored. In addition, a reconstruction strategy must take into account programmes that are already in place.

Socio-economic development incorporates five different aspects that have direct relevance for the transformation of war economies. The first aspect is humanitarian assistance, which includes food security, public health, shelter and the return of refugees and internally displaced persons (IDPs). During a conflict, and because of a war economy, the state is unable to provide many of these services; therefore, a post-conflict reconstruction strategy should ensure that ordinary citizens are provided with the security they so desperately need.

The second aspect of socio-economic development includes repatriation, rehabilitation, reintegration and reconstruction. Particularly important is a disarmament, demobilisation and reintegration (DDR) process that focuses not only on the reintegration of former combatants, but also gives attention to the licit economic opportunities that should be created. Naturally, there are difficulties to this strategy, but it remains vital that ex-combatants are incorporated into the licit economy. ${ }^{81}$

The third aspect covers physical infrastructure, such as roads, ports, airports, electricity and telecommunications. During a war economy, development of infrastructure is either non-existent or is monopolised by suppliers that work closely with the country's elites or other conflict actors. Therefore, it is important that the 
legitimate government be empowered, both politically and financially, to take responsibility for providing its citizens with appropriate physical infrastructure. This is also true for the fourth aspect, comprising of social services like health and education.

Finally, the fifth aspect consists of the economy, where physical infrastructure needs to be rebuilt, employment generated, international trade better regulated, and positive FDI sought. This last aspect is perhaps the most important for ensuring a successful transformation from a war economy to a peace economy given the challenge posed by shadow trading networks and FDI that does not benefit the local economy. ${ }^{82}$

The AU framework includes socio-economic development as one of its focus areas, which is defined as "a multidimensional process that contributes to improved living conditions, improved ability to meet basic needs (such as health, education, and food), the reduction of poverty and inequality and enhanced capacity of human beings to realise their potential". ${ }^{83}$

The socio-economic reconstruction and development section of the AU framework includes a number of objectives:

- $\quad$ addressing the gap between relief and development in order to ensure that a country does not revert to a war economy;

- formulating policies that address social inequity, during the transition, reconstruction and development phases;

- undertaking comprehensive institution building to enhance good economic governance - this should guarantee that war economy actors are discouraged from reverting to previous corruptive behaviour;

- $\quad$ building human resource capacity at local and national levels for policy development, needs assessment, planning, implementation, monitoring and evaluation of programmes and activities. This is especially important because it will create a system that can be actively monitored, and government officials can be held accountable for the country's progress (or lack of progress); and,

- building a technology base to support reconstruction and development and developing physical infrastructure, including transport, communication, energy, water, health, and sanitation. ${ }^{84}$

In addition, the PCRD framework includes a commitment to addressing the root causes of conflict, as well as promoting national and local ownership. The last point is particularly important, as the success or failure of a reconstruction 
strategy often rests on how much involvement local communities had in developing their reconstruction process. ${ }^{85}$

It is important to link post-conflict reconstruction to the transformation of war economies to peace economies. A post-conflict reconstruction strategy needs to work both from a bottom-up and from a top-down perspective. Current approaches tend to focus on building state institutions, which are vital to any reconstruction strategy; however, these approaches tend to neglect the role that civil society has to play. The other problem with a state-centric approach is that civil society groups are lumped together. These often include economic actors who do not necessarily have the same purpose as social groups. In order to overcome the challenge of war economies, war economy actors need to be separated from other civil society actors.

Although most post-conflict reconstruction strategies include issues of political economy, the "economic agendas introduced on the coattails of international intervention have tended to disregard crucial aspects of war economies, especially their regional linkages and the functional aspects of shadow economy activity" ${ }^{86}$ Therefore, a reconstruction strategy must take into account the factors that created the war economy, and gear post-conflict reconstruction towards overcoming the root causes of conflict. In addition, the regional dimension of war economies should be considered, especially in regions where shadow trade networks formed the basis of the war economy. The UN Peacebuilding Framework for Sierra Leone specifically mentions the importance of the sub-regional dimension of peacebuilding, noting that conflict in one West African country often affects a neighbouring country in that region. ${ }^{87}$

\section{Conclusion and recommendations}

Pugh et $\mathrm{al}^{88}$, make several recommendations to overcoming the challenges of war economies. Their study focused on the regional dimension of war economies and their suggestions are certainly relevant African case studies. These recommendations include promoting regional economic development and implementing effective regulation to target conflict trade. In addition, the following practical steps could assist in fully transforming the war economy to a peace economy.

Firstly, the transition to peace is a development-plus challenge, which means, "in addition to the normal challenge of socio-economic development, they must accommodate the extra burden of economic rehabilitation and national reconciliation". ${ }^{89}$ Secondly, the political objective should prevail over the economic objective in all circumstances. Thirdly, external actors, including the donor 
governments and the UN, drive the post-conflict reconstruction process and, therefore, these policy-makers often lack the legitimacy that is required to implement key economic measures. Fourthly, the level of development in a country undergoing post-conflict reconstruction should be measured differently from a case of normal development. Fifthly, development institutions are not the ideal leaders of post-conflict reconstruction and, therefore, African governments should be playing the main role in reconstructing their countries. Lastly, the post-conflict reconstruction plans for African (and other) states should be both simple and flexible. ${ }^{90}$

Finally, the greatest difficulty in the war economy to peace economy transformation process is convincing groups that are making a profit out of war that a peaceful economy provides more stable economic opportunities. However, there is no "how to" guide to deal with the challenge of war economies. Overcoming war economies through the implementation of a post-conflict reconstruction strategy should be treated on a case-by-case basis, based on individual plans, and not through a "one-size-fits-all" approach. It is certainly clear that more work needs to be done, especially in Africa, to overcome the legacy of war economies.

${ }^{1}$ M Berdal and D M Malone, eds. Greed and Grievance: Economic Agendas in Civil Wars (Boulder, CO: Lynne Rienner, 2000), 1.

${ }^{2}$ K Ballentine and J Sherman, eds. The Political Economy of Armed Conflict: Beyond Greed and Grievance (Boulder CO: Lynne Rienner, 2003), 1.

${ }^{3}$ Berdal and Malone, 1 .

${ }^{4}$ Berdal and Malone, 4.

${ }^{5}$ Berdal and Malone, 4.

${ }^{6}$ P Collier. "Doing well out of war." 1999. Available: http://www.worldbank.org/programs/conflict/topic/13188/library/doc? Date Accessed" 4 November 2009.

${ }^{7}$ Berdal and Malone.

${ }^{8}$ Ballentine and Sherman.

${ }^{9}$ P Collier and A Hoeffler. "Greed and grievance in civil war." Oxford Economic Papers, 2004, 56, 563-95.

${ }^{10}$ Ballentine and Sherman, 2-3.

${ }^{11}$ Berdal and Malone, 2.

12 Berdal and Malone, 2.

${ }^{13}$ W Reno. Warlord Politics and African States (Boulder and London: Lynne Rienner 1998).

${ }^{14}$ Ballentine and Sherman, 2.

${ }^{15}$ M Pugh, N Cooper and J Goodhand, eds. War Economies in a Regional Context (Boulder: Lynne Rienner 2004). 
${ }^{16} \mathrm{~S}$ Naidoo. "The role of war economies in understanding contemporary conflicts". Global Dialogue, 5(2), September 2000.

${ }^{17}$ Pugh et al, 8 .

${ }^{18} \mathrm{~J}$ Goodhand. "From war economy to peace economy? Reconstruction and state building in Afghanistan". Journal of International Affairs, 58(1), 2004.

${ }^{19}$ K Fekete. "Experts consider how to transform war economies." 2004. Available: http://www.swissinfo.org/sen/swissinfo.html. Date Accessed: 6 October 2009.

${ }^{20}$ Fekete 2004

${ }^{21}$ M Berdal. "How ‘new' are 'new wars'?” Global Governance, 9, 2003.

${ }^{22}$ Berdal, 477.

${ }^{23}$ P Collier, VL Elliott, H Hegre, A Hoeffler, M Reynal-Queral, and N Sambanis, Breaking the Conflict Trap: Civil War and Development Policy (Washington: World Bank and Oxford University Press 2003).

${ }^{24}$ P Mallampally and KP Sauvant. "Foreign direct investment in developing countries." 1999. Available: http://www.imf.org/external/pubs/ft/fandd/1999/03/mallampa.htm. Date Accessed: 7 October 2009.

${ }^{25}$ Collier 1999.

${ }^{26}$ M Turner and M Pugh. "Towards a new agenda for transforming war economies." Conflict, Security and Development, 6(3), October 2006.

${ }^{27}$ O Richmond. "The problem of peace: Understanding the 'liberal peace'." Conflict, Security \& Development, 6, Number 32006.

${ }^{28}$ Turner and Pugh, 472-473

${ }^{29} \mathrm{~S}$ Woodword. Economic Priorities for Successful Peace Implementation. In Ending Civil Wars: The Implementation of Peace Agreements, edited by S Stedman, D Rothchild and E Cousens (Boulder, Lynne Rienner Publishers 2002).

${ }^{30}$ Turner and Pugh, 472.

${ }^{31}$ Pugh et al, 92.

32 J Galtung. Searching for Peace. The Road to Transcend (London: Pluto 2002).

${ }^{33}$ M Llamazares. "Post-war peacebuilding reviewed - A critical exploration of generic approaches to post-war reconstruction". Centre for Conflict Resolution Working Paper Series (Department of Peace Studies: Bradford University 2005).

${ }^{34} \mathrm{~J}$ Spear. "From political economies of war to political economies of peace: the contribution of DDR after wars of predation". Contemporary Security Policy, 27(1), April 2006.

${ }^{35}$ B Boutros-Ghali. "An agenda for peace: preventative diplomacy, peacemaking and peace-keeping." United Nations Document A/47/277-S/2411 1992.

${ }^{36}$ E M Cousens. Introduction. In Peacebuilding as Politics: Cultivating Peace in Fragile Societies, edited by EM Cousens, C Kumar and K Wermester (Boulder and London: Lynne Rienner Publishers 2001). 
${ }^{37}$ B Boutros-Ghali. Supplement to an agenda for peace. United Nations Document A/50/60-S/1995/1 1995.

${ }^{38}$ United Nations Security Council. Statement by the President of the Security Council. United Nations Document S/PRST/2001/5 2001.

${ }^{39}$ H Hänggi. Approaching Peacebuilding from a Security Governance Perspective. In Security Governance in Post-Conflict Peacebuilding, edited by A Bryden and H Hänggi (Münster: LIT Verlag 2005).

${ }^{40}$ Hänggi 2005, 11.

${ }^{41}$ Centre for Strategic and International Studies. "Post-conflict Reconstruction Task Framework." 2002. Available: http://www.csis.org/isp/pcr/. Date Accessed: 7 June 2009.

${ }^{42}$ NEPAD Secretariat. African Post-Conflict Reconstruction Policy Framework (Midrand: NEPAD Secretariat 2005).

${ }^{43}$ World Bank. Post-Conflict Reconstruction: The Role of the World Bank (Washington: The International Bank for Reconstruction and Development/The World Bank 1998).

${ }^{44} \mathrm{~F}$ Cheru. African Renaissance: Roadmaps to the Challenge of Globalization (London and New York: Zed Books 2002).

${ }^{45}$ School of Advanced International Studies.

${ }^{46}$ School of Advanced International Studies.

${ }^{47}$ PS Douma. The Political Economy of Internal Conflict: A Comparative Analysis of Angola, Colombia, Sierra Leone and Sri Lanka. (The Hague: Netherlands Institute of International Relations, Clingendael 2005).

${ }^{48}$ Douma 2005, 20.

${ }^{49}$ See W Reno, Corruption and State Politics in Sierra Leone, for an explanation of the Shadow State theory.

${ }^{50}$ M Duffield. Globalization, Transborder Trade, and War Economies. In Greed and Grievance, edited by M Berdal and DM Malone (Boulder and London: Lynne Rienner Publishers 2000).

${ }^{51}$ Duffield, 73.

${ }^{52}$ Duffield, 74.

${ }^{53} \mathrm{~K}$ Ballentine and H Nitzschke. The Political Economy of Civil War and Conflict Transformation. In Berghof Handbook Dialogue Series Number 3, Transforming War Economies (Berghof Research Centre for Constructive Conflict Management 2005).

${ }^{54} \mathrm{M}$ Kaldor. New and Old Wars: Organised Violence in a Global Era (Cambridge:

${ }^{55}$ Kaldor, 90 Polity Press 2001)

${ }^{56}$ Goodhand, 257.

${ }^{57}$ Pugh et al, 99.

${ }^{58}$ Goodhand, 257-258.

${ }^{59}$ Collier et al, 13.

${ }^{60}$ Collier et al, 13-14. 
${ }^{61}$ J Goldstein. "War and economic history." 2003. Available: http://www.joshuagoldstein.com/jgeconhi.htm. Date Accessed: 5 September 2009.

${ }^{62}$ Collier 1999.

${ }^{63}$ P Collier. Economic Causes of Civil Conflict and Their Implications for Policy. In Turbulent Peace: The Challenges of Managing International Conflict, edited by CA Crocker, FO Hampson and P Aall (Washington D.C.: United States Institute of Peace Press 2001).

${ }^{64}$ D Keen. Incentives and Disincentives for Violence. In Greed and Grievance, edited by M Berdal and DM Malone (Boulder and London: Lynne Rienner Publishers 2000).

${ }^{65}$ P Collier. The market for civil war. Foreign Policy, 136, May. 2003.

${ }^{66}$ Naidoo 2000, 25-26.

${ }^{67}$ G Mills. "From war to wealth in Africa: Congo must help itself." The Christian Science Monitor, January 12, 2010.

${ }^{68}$ Mail and Guardian. Global witness condemns use of 'conflict minerals'. February 16, 2010.

${ }^{69}$ African Union. "Draft Policy Framework for Post-Conflict Reconstruction and Development." PSD/PCRD/EXP/4(I) 2006.

${ }^{70}$ NEPAD Secretariat 2005, iv - v.

${ }^{71}$ Organisation for Economic Cooperation and Development. "Introductory tip sheet on Peacebuilding." 2005. Available: http://www.oecd.org/dataoecd/13/33/35034078.pdf. Date Accessed: 8 August 2009.

${ }^{72}$ Norwegian Ministry of Foreign Affairs. "Peacebuilding - a Development Perspective." 2004. Available: http://www.odin.dep.no/ud. Date Accessed: 6 January 2010.

${ }^{73}$ Centre for Strategic and International Studies 2002.

${ }^{74}$ NEPAD Secretariat 2005, iv.

${ }^{75}$ African Union 2006, 3-4.

${ }^{76}$ United Nations Security Council. Resolution 60/180 (2005) and United Nations Security Council. 2005. Resolution 1645, December (2005).

${ }^{77}$ United Nations Peacebuilding Commission. "Chairman's Summary: Sierra Leone Country-Specific Meeting.” 2006. Available: http://www.un.org/peace/peacebuilding/CountrySpecific\%20Configurations/Sierra\%20Leone/Chairman's\%20summary\%2 0(12\%20October\%202006).pdf. Date Accessed: 3 November 2009.

${ }^{78}$ United Nations Security Council, Document 458 Report of the Peacebuilding Commission on its first session, 25 July 2007.

${ }^{79}$ NEPAD Secretariat 2005, iv-v.

${ }^{80}$ H Hänggi. Approaching Peacebuilding from a Security Governance Perspective. In Security Governance in Post-Conflict Peacebuilding, edited by A Bryden and H Hänggi (Münster: LIT Verlag 2005). 
${ }^{81}$ J Spear. "From political economies of war to political economies of peace: The contribution of DDR after wars of predation." Contemporary Security Policy. 27(1), April, 2006.

${ }^{82}$ NEPAD Secretariat 2005, 15

${ }^{83}$ African Union 2006, 4.

${ }^{84}$ Africa Union 2006, 4.

${ }^{85}$ African Union 2006, 4-5.

${ }^{86}$ Pugh et al 2004, 3.

${ }^{87}$ United Nations Peacebuilding Commission. Sierra Leone Peacebuilding Cooperation Framework. PBC/2/SLE/1 (New York: United Nations 2007).

${ }^{88}$ Pugh et al 2004, 226-234.

${ }^{89} \mathrm{G}$ del Castillo. Rebuilding War-Torn States: The Challenge of Post-Conflict Economic Reconstruction (Oxford: Oxford University Press 2008).

${ }^{90}$ Del Castillo 2008, 40-47. 